\title{
Temporal variations in the diet of the squid Moroteuthis ingens at Macquarie Island: stomach contents and fatty acid analyses
}

\author{
Katrina L. Phillips ${ }^{1, *}$, George D. Jackson ${ }^{1}$, Peter D. Nichols ${ }^{2,3}$ \\ ${ }^{1}$ Institute of Antarctic and Southern Ocean Studies, University of Tasmania, Private Bag 77, Hobart, Tasmania 7001, Australia \\ ${ }^{2}$ CSIRO Marine Research, GPO Box 1538, Hobart, Tasmania 7001, Australia \\ ${ }^{3}$ Antarctic CRC, University of Tasmania, Private Bag 80, Hobart, Tasmania 7001, Australia
}

\begin{abstract}
The onychoteuthid squid Moroteuthis ingens was collected as by-catch from a commercial trawl fishery in the vicinity of Macquarie Island, within the Pacific sector of the Southern Ocean. Squid were collected during 3 austral summers and 1 austral winter between January 1995 and June 2000. Stomach contents and fatty acid profiles of both mantle and digestive gland tissues were used to determine if the diet of $M$. ingens was subject to temporal variations in this region. Discriminant analysis (DA) of stomach contents data and digestive gland fatty acid data indicated that the diet varied significantly on an interannual basis, most likely due to an increase in the consumption of the myctophid Gymnoscopelus nicholsi during the summer of 1999 relative to the summers of 1995 and 2000. Comparisons with oceanographic data reveal that the summer of 1999 was a period of warmer sea-surface temperatures and reduced primary production compared to the summers of 1995 and 2000. Fluctuations in oceanographic conditions may have underpinned variations in the availability of prey during the study period. DA of digestive gland fatty acid data also indicated that the diet varied significantly between the summer and winter of 2000. Stomach contents data indicate that the myctophid Electrona carlsbergi replaced Krefftichthys anderssoni as a key prey species for M. ingens during the winter period, as has been observed for other marine predators in the sub-Antarctic Southern Ocean. A comparison of methods reveals that, while fatty acid analyses greatly aid the interpretation of stomach contents data, both techniques are subject to limitations and are best used in combination.
\end{abstract}

KEY WORDS: Myctophids · Digestive gland $\cdot$ Mantle $\cdot$ Cephalopods $\cdot$ Southern Ocean

Resale or republication not permitted without written consent of the publisher

\section{INTRODUCTION}

Cephalopods are a key intermediate component of the sub-Antarctic Southern Ocean ecosystem, occupying a niche that is characterised by epipelagic fish in oceans at lower latitudes (Rodhouse \& White 1995). The consumption of squid and other cephalopods by toothed whale, seal and seabird species has been estimated at $>30$ million tonnes $\mathrm{yr}^{-1}$ (Clarke 1983); cephalopods therefore represent an important mechanism by which energy is transferred to top trophic levels. Cephalopods have rarely attracted the attention of major research programs conducted in the Southern Ocean (Okutani 1994), and it is likely that they comprise a much greater pro- portion of the biomass of the midwater community than most ecosystem models allow (Clarke 1996). It has become important to increase the number of ecological studies of cephalopods, particularly studies of trophic interactions between cephalopods and their prey (Piatkowski et al. 2001). The ecological role of squid as consumers in the Southern Ocean is poorly documented; prior to 1986, published results were available for fewer than 200 specimens (Kock 1987). While the number of studies has increased markedly since this time, it has been possible to collect only basic descriptive dietary data for most species examined so far, and very few published studies have investigated ecological variations in the diet of a Southern Ocean squid species. 
This study investigates interannual and seasonal variations in the diet of the onychoteuthid squid Moroteuthis ingens. Squid populations have been observed to fluctuate widely from year to year (Piatkowski et al. 2001), possibly in response to prey availability. Jackson et al. (1998a) and Cherel \& Weimerskirch (1999) have suggested that the population size of $M$. ingens fluctuates on an interannual basis over the Patagonian Shelf and within waters surrounding the Crozet Archipelago, and Cherel \& Weimerskirch (1999) have related interannual variations in the size of this species to poor food availability. Previous dietary studies have shown that $M$. ingens consumes large amounts of myctophid fish (Jackson et al. 1998b, Phillips et al. 2001), as do other squid distributed in the PFZ (Lubimova 1985, Kock 1987, Rodhouse et al. 1992). Myctophids are sparsely distributed over large areas of the Southern Ocean, but can be found in dense concentrations in restricted areas, particularly within the PFZ (Filin et al. 1991, Kozlov 1995). The movement of these shoals of myctophids over time is highly variable and dependent on oceanographic conditions (Filin et al. 1991), and their presence or absence may significantly impact the diet of a predator such as $M$. ingens at a given location.

We have combined conventional stomach contents analyses with complementary fatty acid techniques and expanded on a previous dietary study of Moroteuthis ingens where it was established that lipid stored in the digestive gland was a unique source of fatty acid dietary tracers (Phillips et al. 2001). Fatty

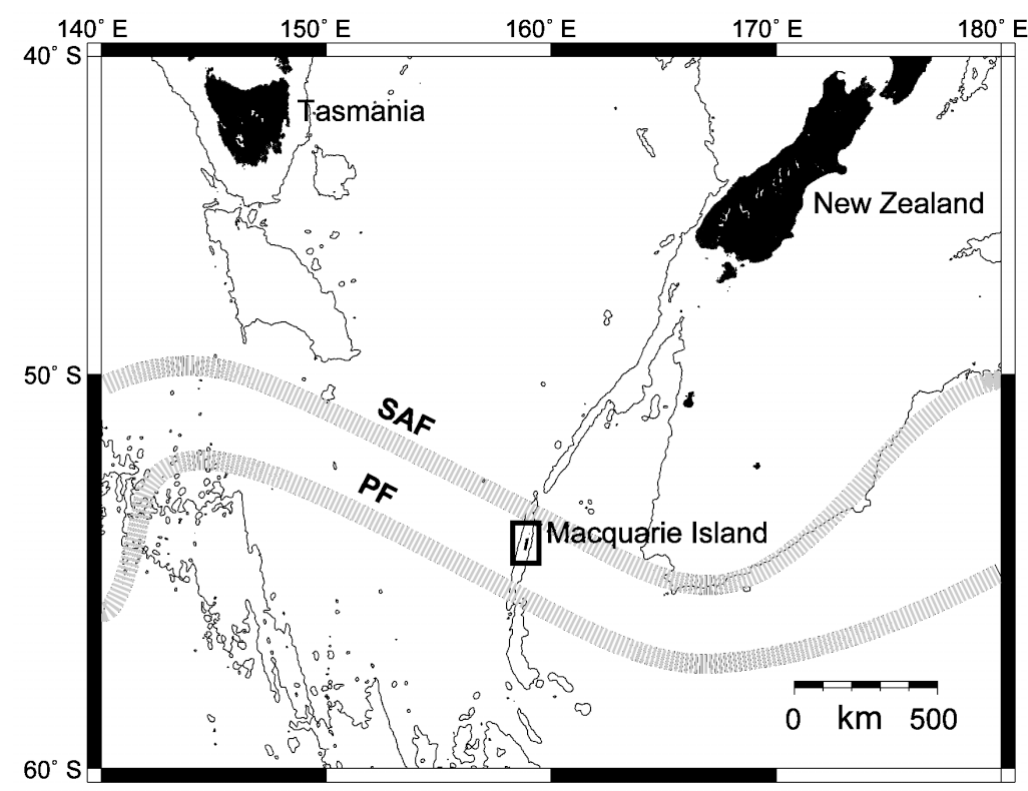

Fig. 1. The location of Macquarie Island relative to Tasmania (Australia) and New Zealand in the Pacific sector of the Southern Ocean. The $3000 \mathrm{~m}$ bathymetry contour and the average locations of the sub-Antarctic Front (SAF) and Polar Front (PF) are shown acid dietary tracers have been used to explore dietary relationships in a number of diverse marine organisms (Mourente \& Tocher 1993, Graeve et al. 1994, Raclot et al. 1998, Cripps et al. 1999, Navarro \& Villanueva 2000), and their use is based on the assumption that many fatty acids in the marine environment can only be biosynthesised by certain phytoplankton and macroalgae species and are thus essential dietary components for higher trophic levels (Sargent 1976, Ackman 1980). Dietary lipid is deposited in the digestive gland of some oegopsid squid species with little or no modification, and digestive gland fatty acids may accumulate over time to provide a history of dietary intake (Phillips et al. 2002). Analysis of digestive gland fatty acid composition can provide further insights into the diet of $M$. ingens that cannot be determined from conventional stomach content analyses, as conventional analyses provide only an 'instantaneous snapshot' of the diet.

\section{MATERIALS AND METHODS}

Squid collection. One hundred and sixty-eight specimens of Moroteuthis ingens were collected as bycatch from the commercial Patagonian toothfish (Dissostichus eleginoides) fishery at numerous locations on the continental slope surrounding Macquarie Island $\left(54^{\circ} 30^{\prime} \mathrm{S}, 158^{\circ} 55^{\prime} \mathrm{E}\right.$; Fig. 1) within the Polar Frontal Zone (PFZ). Collections were made over 3 austral summer fishing seasons and 1 exploratory season conducted during the austral winter between January 1995 and June 2000. The squid were collected by Australian Fisheries Management Authority (AFMA) observers on board the commercial trawler 'Austral Leader'. Fifty-two squid were collected during the 1994-1995 austral summer (5 January 1995-10 February 1995); these are referred to as '1995 summer' squid. 1995 summer squid were collected from 12 locations around the island at depths from $910 \mathrm{~m}$ to $990 \mathrm{~m}$. Fifty-seven squid were collected from 22 locations during the 1998-1999 austral summer ('1999 summer' squid, 16 October 1998-18 January 1999) at depths from $251 \mathrm{~m}$ to $1078 \mathrm{~m}$. Twenty-eight squid were collected during the 1999-2000 austral summer ('2000 summer squid', 5 January 2000-4 February 2000) from 6 locations at depths from $508 \mathrm{~m}$ to $1145 \mathrm{~m}$, and 31 squid were collected during the 2000 austral winter ('2000 winter squid'), 21 June to 28 June from 11 locations around the island at depths from $611 \mathrm{~m}$ to $965 \mathrm{~m}$. All squid were frozen 
after collection at $-20^{\circ} \mathrm{C}$ and returned to Hobart for dissection and analysis. Individuals were allocated a maturation stage according to a subjective 5-point scale (after Lipinski 1979).

Stomach contents analyses. The stomach contents data of 1999 summer squid have been previously published (Phillips et al. 2001) and are included here for comparison. Stomachs from all intact squid collected during the 1995 summer, 2000 summer and 2000 winter were examined for contents, and stomach fullness was determined on a 6-point subjective scale (Jackson et al. 1998b). Stomach contents were rinsed through a $500 \mu \mathrm{m}$ mesh sieve and sorted in a petri dish under a dissection microscope. Remains were identified to 1 of 3 major prey categories: fish, cephalopod or crustacean. The major prey category that comprised the largest part of the contents of an individual stomach was recorded as the 'primary prey item' for that stomach.

Sagittal otoliths were removed, dried and stored before identification to species level where possible (Williams \& McEldowney 1990, Smale et al. 1995). Otoliths of Gymnoscopelus nicholsi are difficult to distinguish from otoliths of $G$. piabilis, as are otoliths of G. fraseri from G. bolini (Williams \& McEldowney 1990, D. Williams pers. comm. 2002). This is particularly so when otoliths have been eroded after partial digestion. Therefore these otoliths were not identified to species level, but were grouped as either G. nicholsi/piabilis or G. fraseri/bolini. When in good condition, otolith lengths $(\mathrm{mm})$ were measured by image analysis with a Hitachi HV-C20 camera and Optimus version 6.2 (Media Cybernetics), and regression equations from Williams \& McEldowney (1990) were used to estimate standard lengths of fish prey. Regression equations for $G$. nicholsi and $G$. fraseri were used to represent G. nicholsi/piabilis and G. fraseri/bolini, respectively. When large amounts of fish remains were found without (or with very few) eye lenses or otoliths, it was assumed that fish heads had been discarded and the incidence was recorded. Cephalopod beaks were stored in $75 \%$ ethanol prior to identification to genus and, where possible, species level (Clarke 1986); squid flesh such as tentacular clubs, funnel-locking cartilage and gladii was also stored in $75 \%$ ethanol. Statoliths were stored dry in small plastic bags. Crustacean remains were stored in $75 \%$ ethanol and identified to broad group categories (J. Kitchener pers. comm.).

Lipid extraction and fatty acid analyses. Lipid was extracted from fifteen 1995 summer squid (8 female, 7 male), twenty 1999 summer squid (13 female, 7 male), ten 2000 summer squid ( 6 female, 4 male) and five 2000 winter squid (all female). Only females of maturity stage III and males of maturity stage $\mathrm{V}$ were selected for fatty acid analysis; animals with damaged digestive glands were excluded from analyses. A small tissue sample (ca. $1 \mathrm{~g}$, taken from the ventral mantle) and the whole digestive gland of each corresponding animal was collected. These were stored frozen at $-20^{\circ} \mathrm{C}$ and retained for lipid and fatty acid analysis. Whole digestive glands were homogenised in a handheld blender and a $0.25-0.5 \mathrm{~g}$ subsample was taken for lipid extraction. Mantle tissue samples were ground in a mortar and pestle prior to extraction.

All tissue samples were extracted overnight using a modified (Bligh \& Dyer 1959) extraction in a one-phase methanol:chloroform:water solvent mixture $(2: 1: 0.8$ $\mathrm{v}: \mathrm{v}: \mathrm{v})$. Phases were separated the following day by addition of chloroform and water (final solvent ratio, 1:1:0.9 v:v:v [methanol:chloroform:water]). Lipids were recovered in the lower chloroform phase, and the solvent removed under vacuum to give the total solvent extract (TSE); these were weighed to obtain total lipid content ( $\%$ wet mass). All samples were made up to a known volume in chloroform and stored at $-20^{\circ} \mathrm{C}$.

An aliquot of the TSE was transmethylated at $80^{\circ} \mathrm{C}$ for $2 \mathrm{~h}$ in a 10:1:1 v:v:v mixture of methanol:hydrochloric acid:chloroform to produce fatty acid methyl esters (FAME). FAME were partitioned by the addition of water and extracted with 4:1 hexane:chloroform $\mathrm{v}: \mathrm{v}$ under nitrogen, then silylated at $60^{\circ} \mathrm{C}$ overnight in N,O-bis-(trimethylsilyl)-triflouracetamide (BSTFA). FAME were then reduced under nitrogen and stored in chloroform at $-20^{\circ} \mathrm{C}$. FAME were analysed by gas chromatography using a Hewlett Packard 5890A GC equipped with a HP-5 cross-linked methyl silicone fused capillary column, an FID, a split/splitless injector and a HP 7673A auto sampler. Helium was the carrier gas, and pressure was maintained at $65 \mathrm{kPa}$. Samples were injected in splitless mode with an oven temperature of $50^{\circ} \mathrm{C}$, and the temperature was ramped to $150^{\circ} \mathrm{C}$ at $30^{\circ} \mathrm{C} \mathrm{min}{ }^{-1}$, then to $250^{\circ} \mathrm{C}$ at $2^{\circ} \mathrm{C} \mathrm{min}^{-1}$, and finally to $300^{\circ} \mathrm{C}$ at $5^{\circ} \mathrm{C} \mathrm{min}^{-1}$. Peaks were quantified with Waters Millennium software (Milford). Confirmation of component identification was achieved by gas chromatography-mass spectrometry (GC-MS) analysis using a Finnigan Thermoquest GCQ GC-MS fitted with an on-column injector.

Statistical analyses. The abundance of prey in the stomach contents of Moroteuthis ingens was described by percentage frequency of occurrence (\%FO), percentage numerical importance $(\% \mathrm{NI})$ and total number (N). The \%FO was determined from the number of stomachs in season $k$ containing prey species $h$ as a percentage of the total number of stomachs examined for season $k_{;} \% \mathrm{NI}$ was determined as the number of prey species $h$ consumed during season $k$ as a percentage of the total number of prey items consumed in season. A prey diversity index was determined as the total number of identifiable fish, cephalopod and crusta- 
cean species per individual stomach. Analyses of stomach contents data were conducted by excluding those prey species that occurred rarely in the diet of $M$. ingens; furthermore, unidentified fish, cephalopod and crustacean categories were excluded from analysis, as these did not consistently represent a particular prey type. Dietary overlap between seasons was determined from stomachs containing identifiable hard remains using a percentage similarity index (\%PSI) adapted from Goldsworthy et al. (2001a):

$$
\% \mathrm{PSI}_{i j}=100 \times\left(1.0-0.5 \sum_{h=1}^{S}\left(\left|S_{h i}-S_{h j}\right|\right)\right.
$$

where $\mathrm{S}_{h i}$ is the proportion by numerical importance of prey species or category $h$ in season $i, S_{h j}$ is the proportion by numerical importance of prey species or category $h$ in season $j$, and $s$ is the number of prey species or categories. Dietary overlap was compared using 2 different groupings of prey. Firstly, $h$ represented each of 10 individual fish and cephalopod species that passed the arbitrary selection criteria of $\geq 5 \%$ NI in 2 or more groups (Electrona carlsbergi, Electrona subaspera, Gymnoscopelus braueri, Gymnoscopelus nicholsi/ piabilis, Gymnoscopelus spp., Krefftichthys anderssoni, Lampanyctus achiris, Protomyctophum spp., Gathylagus antarcticus and Stoloteuthis sp.); secondly, $h$ represented 1 of 4 prey categories defined as either myctophid fish, other fish, sepiolid cephalopods or other cephalopods. Crustacean prey could not be included in analyses of dietary overlap as the number of crustacean prey consumed by an individual squid could not be accurately determined from exoskeleton remains.

Complete linear canonical discriminant analysis (DA) and linear canonical DA with forward-stepwise entry of variables were used to classify individuals to season using both prey species presence-absence data and fatty acid $\mathrm{mg} \mathrm{g}^{-1}$ data. Each data set was used to investigate dietary variations between (1) the 1995, 1999 and 2000 summer and (2) the 2000 summer and 2000 winter. Arbitrary selection criteria were set where a prey species must be abundant at or above $5 \%$ FO in at least 2 groups. Therefore, comparisons between the summers were made using 12 prey variables (Elec- trona antarctica, Electrona carlsbergi, Electrona subaspera, Gymnoscopelus braueri, Gymnoscopelus fraseri/bolini, Gymnoscopelus nicholsi/piabilis, Gymnoscopelus spp., Krefftichthys anderssoni, Protomyctophum spp., Bathylagus antarcticus, Stoloteuthis sp. and calanoid copepods); comparisons between the 2000 summer and 2000 winter were made using only 4 prey variables (E. carlsbergi, G. nicholsi/piabilis, Protomyctophum spp. and Stoloteuthis sp.).

Fatty acids that contributed a mean of $<0.5 \%$ (of total fatty acids) were excluded from DA. For digestive gland tissue, analyses were performed using 15 (see Table 6) and 19 (see Table 7) fatty acids, respectively.

One-way ANOVA with Tukey's post-hoc test, ANCOVA and 2-tailed $t$-tests assuming unequal variance were also conducted on general biological data, stomach contents data, total lipid and fatty acid data. All statistical analyses were conducted using SPSS 10.0 for Macintosh (SPSS).

\section{RESULTS}

\section{General biology}

The mantle length (ML, mm) and total mass (TM, g) were recorded for each individual, excluding 7 squid collected during the 2000 winter (Table 1). Females had a significantly higher mean ML and TM than males ( $p<0.01$ in each case, except during the 2000 winter where $\mathrm{p}<0.05$ for $\mathrm{ML}$ ), as has been previously documented for this sexually-dimorphic species (Lipinski \& Linkowski 1986, Jackson \& Mladenov 1994). No significant differences in ML were observed for either sex between seasons. Regression of log TM against the covariate ML showed that there were also no significant differences in TM between seasons for either sex. During summer periods, all females were immature and the modal maturity was stage III, whereas most males were mature (maturity stage V). During the winter, almost half of the females were of maturity stage II, although the modal maturity was again stage III. No mature males were collected during winter.

Table 1. Moroteuthis ingens. Average mantle length (ML, mm) and total mass (TM, g) of squid collected over 3 summers and 1 winter period. n: sample size

\begin{tabular}{|c|c|c|c|c|c|c|}
\hline & \multicolumn{3}{|c|}{ Females } & \multirow[b]{2}{*}{$\mathrm{n}$} & \multirow{2}{*}{$\begin{array}{c}\text { Males } \\
\text { ML } \\
\text { mean } \pm \mathrm{SD}\end{array}$} & \multirow[b]{2}{*}{$\begin{array}{c}\mathrm{TM} \\
\text { mean } \pm \mathrm{SD}\end{array}$} \\
\hline & $\mathrm{n}$ & $\begin{array}{c}\mathrm{ML} \\
\text { mean } \pm \mathrm{SD}\end{array}$ & $\begin{array}{c}\mathrm{TM} \\
\text { mean } \pm \mathrm{SD}\end{array}$ & & & \\
\hline 1995 summer & 26 & $320.6 \pm 44.6$ & $1018.0 \pm 369.6$ & 26 & $278.5 \pm 38.8$ & $602.0 \pm 210.9$ \\
\hline 1999 summer & 31 & $303.9 \pm 40.9$ & $906.7 \pm 334.8$ & 26 & $256.7 \pm 36.0$ & $511.1 \pm 209.6$ \\
\hline 2000 summer & 23 & $325.3 \pm 45.7$ & $1093.7 \pm 450.9$ & 5 & $261.2 \pm 22.4$ & $489.0 \pm 123.5$ \\
\hline 2000 winter & 18 & $279.1 \pm 82.6$ & $866.1 \pm 612.6$ & 6 & $216.8 \pm 21.5$ & $312.2 \pm 94.7$ \\
\hline
\end{tabular}




\section{Stomach contents}

Most stomachs collected during the 1995 summer, 2000 summer and 2000 winter contained some contents although few were completely full; modal full- ness was consistently recorded as 1 and 2 on a 6 -point subjective scale. Most stomach contents were in a medium-to-high state of digestion. A large number of prey species were identified (Table 2); however, nearly $50 \%$ of stomachs with identifiable hard remains con-

Table 2. Total number $(\mathrm{N})$, percentage numerical importance (\%NI) and percentage frequency of occurrence (\%FO) of prey categories and prey species consumed by Moroteuthis ingens over 3 summer and 1 winter period. n: total number of stomachs examined per collection period

\begin{tabular}{|c|c|c|c|c|c|c|c|c|c|c|c|c|}
\hline \multirow[t]{2}{*}{ Prey item } & \multicolumn{3}{|c|}{$\begin{array}{l}1995 \text { summer } \\
\quad(\mathrm{n}=52)\end{array}$} & \multicolumn{3}{|c|}{$\begin{array}{l}1999 \text { summer } \\
\quad(\mathrm{n}=50)\end{array}$} & \multicolumn{3}{|c|}{$\begin{array}{l}2000 \text { summer } \\
\quad(\mathrm{n}=20)\end{array}$} & \multicolumn{3}{|c|}{$\begin{array}{l}2000 \text { winter } \\
\quad(\mathrm{n}=31)\end{array}$} \\
\hline & $\mathrm{N}$ & $\% \mathrm{NI}$ & $\% \mathrm{FO}$ & $\mathrm{N}$ & $\% \mathrm{NI}$ & $\% \mathrm{FO}$ & $\mathrm{N}$ & $\% \mathrm{NI}$ & $\% \mathrm{FO}$ & $\mathrm{N}$ & $\% \mathrm{NI}$ & $\% \mathrm{FO}$ \\
\hline \multicolumn{13}{|l|}{ FAMILY MYCTOPHIDAE } \\
\hline Electrona antarctica & 7 & 2 & 6 & 16 & 5 & 12 & & & & & & \\
\hline Electrona carlsbergi & 72 & 23 & 19 & 6 & 2 & 6 & 2 & 3 & 10 & 39 & 48 & 13 \\
\hline Electrona subaspera & 21 & 7 & 21 & 30 & 9 & 16 & 1 & 1 & 5 & & & \\
\hline Electrona spp. & 1 & 0.3 & 2 & 2 & 1 & 2 & 1 & 1 & 5 & & & \\
\hline Gymnoscopelus braueri & 21 & 7 & 2 & 30 & 9 & 18 & 14 & 19 & 15 & & & \\
\hline Gymnoscopelus fraseri/bolini & 10 & 3 & 8 & 28 & 9 & 12 & & & & 2 & 2 & 6 \\
\hline Gymnoscopelus hintonoides & & & & 3 & 1 & 2 & & & & & & \\
\hline Gymnoscopelus nicholsi/piabilis & 2 & 1 & 4 & 28 & 9 & 24 & 19 & 26 & 25 & 4 & 5 & 6 \\
\hline Gymnoscopelus opisthopterus & 2 & 1 & 2 & & & & & & & & & \\
\hline Gymnoscopelus spp. & & & & 42 & 13 & 10 & 9 & 12 & 25 & 1 & 1 & 3 \\
\hline Hintonia spp. & & & & 2 & 1 & 2 & & & & & & \\
\hline Krefftichthys anderssoni & 83 & 27 & 19 & 46 & 14 & 16 & 5 & 7 & 15 & & & \\
\hline Lampanyctus achiris & 14 & 5 & 6 & & & & & & & 11 & 14 & 13 \\
\hline Protomyctophum bolini & 1 & 0.3 & 2 & 15 & 5 & 12 & & & & & & \\
\hline Protomyctophum normani & & & & & & & 1 & 1 & 5 & & & \\
\hline Protomyctophum spp. & 4 & 1 & 8 & 34 & 10 & 22 & 1 & 1 & 5 & 10 & 12 & 6 \\
\hline \multicolumn{13}{|l|}{ OTHER FISH } \\
\hline Bathylagus antarcticus & 24 & 8 & 21 & 17 & 5 & 18 & & & & 8 & 10 & 10 \\
\hline Persparsia kopua & 1 & 0.3 & 2 & & & & & & & & & \\
\hline Macrourus carinatus? & & & & & & & & & & 1 & 1 & 3 \\
\hline Poromitra crassiceps & & & & & & & 1 & 1 & 5 & & & \\
\hline Unidentified Channichthyid & 1 & 0.3 & 2 & & & & 6 & 8 & 5 & & & \\
\hline Paradiplospinus gracilis & 2 & 1 & 4 & & & & 9 & 12 & 15 & & & \\
\hline Unidentified & 13 & 4 & 12 & & & & 1 & 1 & 5 & & & \\
\hline Total fish & 279 & 90 & 85 & 299 & 92 & 96 & 70 & 95 & 75 & 76 & 94 & 58 \\
\hline$\%$ FO as primary prey & & & 77 & & & 78 & & & 65 & & & 58 \\
\hline$\%$ FO fish heads discarded & & & 19 & & & 6 & & & 15 & & & 0 \\
\hline \multicolumn{13}{|l|}{ CEPHALOPODS } \\
\hline Brachioteuthis spp. & & & & 3 & 1 & 6 & & & & & & \\
\hline Cranchiid spp. & & & & 1 & 0.3 & 2 & & & & 1 & 1 & 3 \\
\hline Mastigoteuthis spp. & 1 & 0.3 & 2 & & & & & & & & & \\
\hline Megalocranchia spp. & 1 & 0.3 & 2 & & & & & & & & & \\
\hline Moroteuthis ingens & 1 & 0.3 & 2 & & & & 1 & 1 & 5 & & & \\
\hline Octopoteuthis spp. & & & & & & & & & & 1 & 1 & 3 \\
\hline Sepiolidae & 3 & 1 & 4 & & & & & & & & & \\
\hline Stoloteuthis spp. & 23 & 7 & 25 & 6 & 2 & 12 & 1 & 1 & 5 & 2 & 2 & 6 \\
\hline Unidentified & 2 & 1 & 4 & 16 & 5 & 8 & 2 & 3 & 10 & 1 & 1 & 3 \\
\hline Total cephalopods & 31 & 10 & 42 & 26 & 8 & 47 & 4 & 5 & 35 & 5 & 6 & 19 \\
\hline$\% \mathrm{FO}$ as primary prey & & & 12 & & & 13 & & & 10 & & & 3 \\
\hline \multicolumn{13}{|l|}{ CRUSTACEANS } \\
\hline Amphipods & & & & & & 4 & & & & & & \\
\hline Calanoid copepods & & & 12 & & & 8 & & & & & & \\
\hline Mysids & & & 2 & & & & & & & & & \\
\hline Natant decapods & & & 4 & & & & & & 10 & & & 3 \\
\hline Total crustaceans & & & 13 & & & 9 & & & 5 & & & 10 \\
\hline$\% \mathrm{FO}$ as primary prey & & & 0 & & & 0 & & & 0 & & & 3 \\
\hline
\end{tabular}




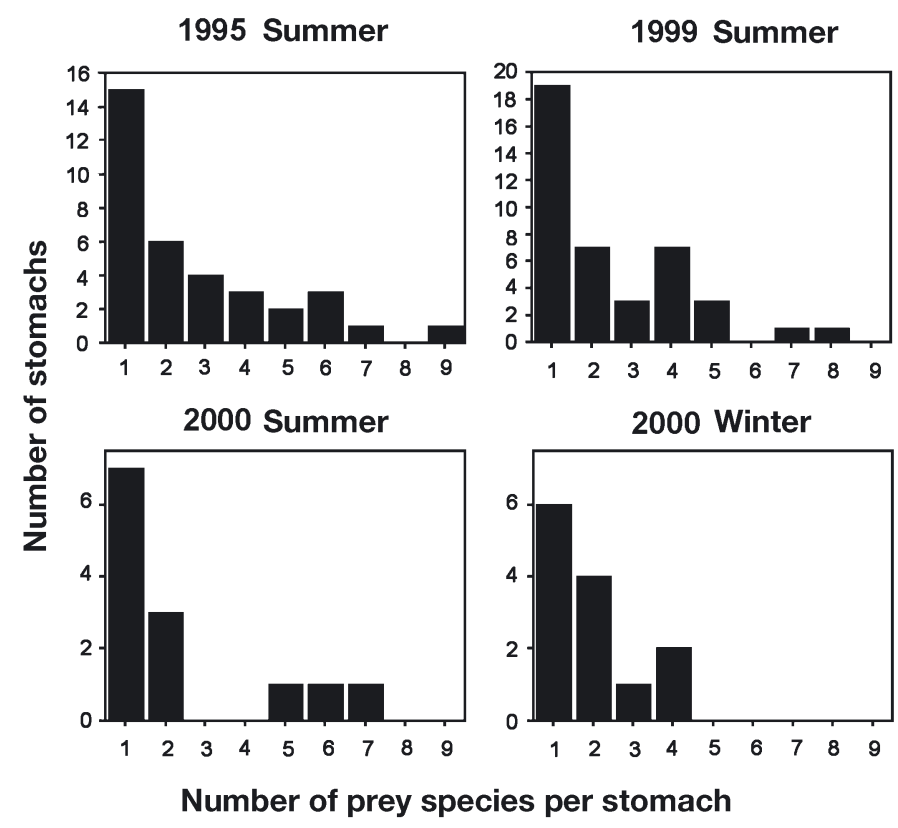

Fig. 2. Moroteuthis ingens. Frequency distribution of the number of prey species identified in squid stomachs

tained only 1 prey species (Fig. 2). The prey-diversity index for individual stomachs did not vary significantly between summers and the 2000 winter, and the mean prey-diversity index over the collection period was low at 2.5 .

Fish were most commonly identified as the primary prey (Table 2), with at least 21 species identified. Only 3 fish species were identified in every collection period: Electrona carlsbergi, Gymnoscopelus nicholsi/ piabilis and Protomyctophum spp. A total of 14 species of myctophid fish were identified, in addition to another 7 fish species from 7 different families that generally contributed only minor amounts to the diet (with the exception of Bathylagus antarcticus and Paradiplospinus gracilis). The number of fish prey consumed by Moroteuthis ingens during the 2000 winter $(7$ species) was considerably less than the number consumed during summer periods (11 to 16 species). Standard lengths (SL) of fish prey were estimated for 9 species (Fig. 3). M. ingens consumed a large range of fish of different sizes, from small individuals of Krefftichthys anderssoni (20 to $50 \mathrm{~mm} \mathrm{SL}$ ) to individuals of the elongate $P$. gracilis that exceeded $400 \mathrm{~mm}$ SL.

Cephalopod prey was consumed during every season, although they were not often the primary prey item (Table 2). Lower rostral length (LRL) measurements were not recorded due to the small size of the cephalopod beak remains, and thus no estimates of cephalopod prey size are available. Most beaks were no larger than $3 \mathrm{~mm}$ crest length, thus precluding accurate measurement of the LRL using callipers. The most common species consumed was the sepiolid Stoloteuthis sp., particularly during the 1995 summer, when it was identified in $25 \%$ of stomachs and comprised $74 \%$ of the identifiable cephalopod remains. This species may represent a Macquarie Island population of Stoloteuthis leucoptera, which has been collected from the Kerguelen plateau in the Indian Ocean sector of the Southern Ocean (Nesis 1987). The Australian Antarctic Division has collected specimens of Stoloteuthis sp. in the vicinity of Macquarie Island (unpubl. data). However, to our knowledge, the presence of this or similar sepiolid species at Macquarie Island has not been previously published, either from pelagic surveys or from the prey remains of vertebrate predators.

Crustacean remains were identified in relatively few stomachs, and only comprised the primary prey group in 1 individual stomach collected during the 2000 winter (Table 2). Most crustacean remains were highly digested and could not be identified beyond broad group categories. Most remains appeared to be from natant decapods and calanoid copepods, of which at least 3 species were consumed over the study period. Myctophid fish consume large amounts of copepods (Pakhomov et al. 1996, Gaskett et al. 2001); therefore, such crustacean remains may derive from secondary ingestion via myctophids rather than from direct predation.

Indices of prey abundance (N, \% NI and \%FO) varied considerably between sampling periods. Abundant prey species in the diet of Moroteuthis ingens during the 1995 summer were Electrona carlsbergi, Krefftichthys anderssoni, Bathylagus antarcticus and Stoloteuthis sp. (Table 2). K. anderssoni was also an important prey during the summer of 1999, in addition to Electrona subaspera, Gymnoscopelus braueri and Gymnoscopelus nicholsi/piabilis. During the 2000 summer, abundant prey species were $G$. braueri, $G$. nicholsi/piabilis, Gymnoscopelus spp. and Paradiplospinus gracilis, whereas E. carlsbergi, Lampanyctus achiris and Protomyctophum spp. were important species during the 2000 winter. Indices of dietary overlap using 10 prey species categories indicated that the 1999 summer and 2000 summer were most similar, with a \%PSI of $64.50 \%$ (Table 3 ). Dietary overlap between the 1995 summer and the 1999 summer was less at $59.57 \%$, and the overlap between 1995 summer and 2000 summer was reduced to $43.22 \%$. The overlap between the 2000 summer and 2000 winter was $30.15 \%$.

When the overlap between sampling periods was determined using 4 prey categories instead of individual species, indices of overlap were much higher and 

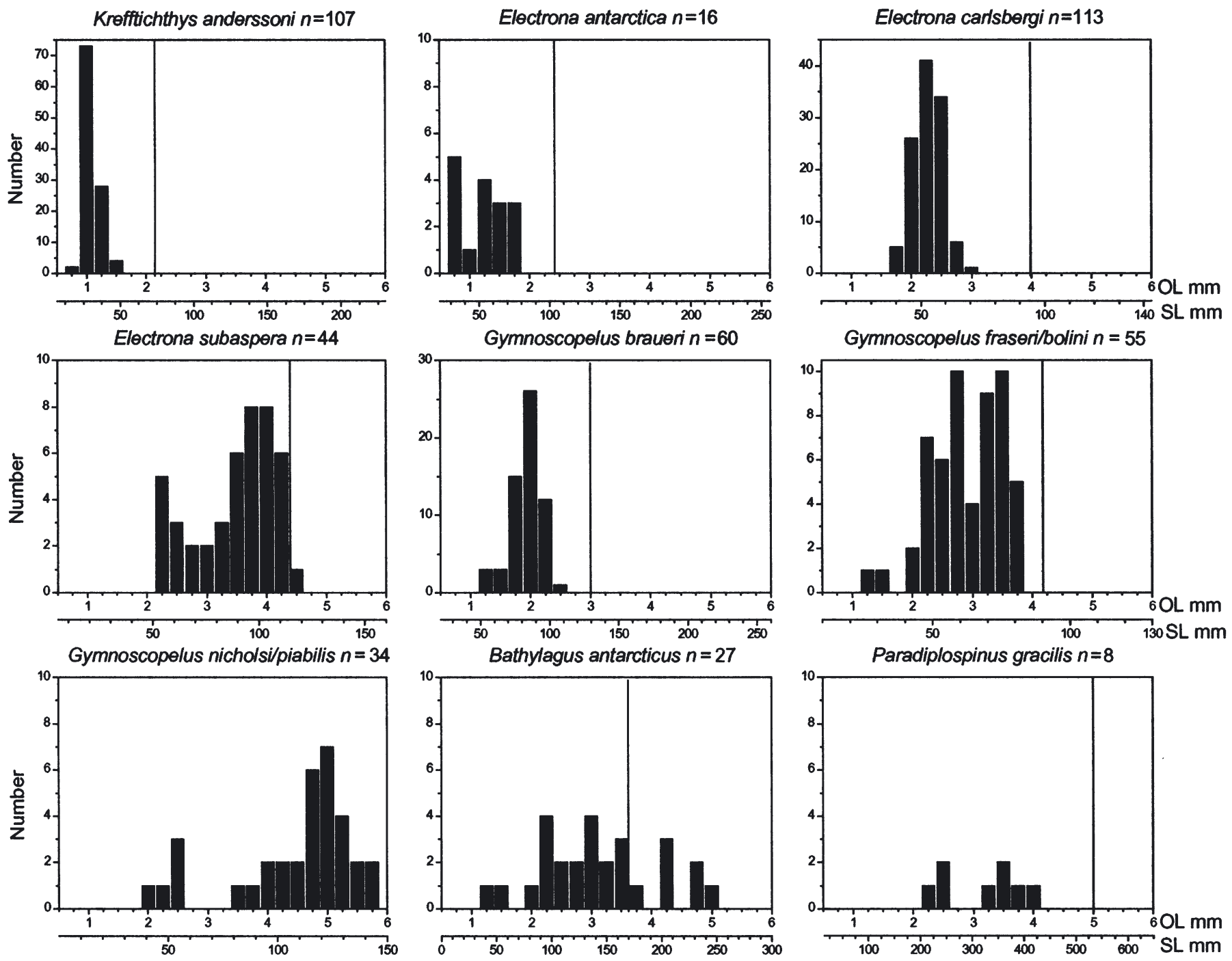

Fig. 3. Otolith length (OL) and estimated standard lengths (SL) of 9 species of fish consumed by Moroteuthis ingens. Vertical lines indicate the maximum length recorded for most fish species; Gymnoscopelus nicholsi attain 160 mm (Smith \& Heemstra 1986, Hulley 1990). n: number of otoliths measured per species

different patterns were also observed (Table 3). The 1999 summer and 2000 winter were most similar with an overlap of $92.7 \%$, whereas the 1999 summer and 2000 summer were least similar with an overlap of $80.5 \%$. Inconsistent trends in dietary overlap between 10 prey species and 4 prey categories indicate that this technique is highly sensitive to the method of grouping (Goldsworthy et al. 2001a). Nevertheless, it appears from both methods of grouping that the diet of Moroteuthis ingens changed markedly from the 2000 summer to the 2000 winter.

Complete linear canonical DA of stomach contents data indicated that the summer diet of Moroteuthis ingens varied on an interannual basis (Wilk's lambda = 0.470 , Approx. $F=2.866, \mathrm{p}<0.01$ ). Two prey variables were incorporated into forward-stepwise DA of the
Table 3. Moroteuthis ingens. Dietary overlap between 3 summers and 1 winter period. Dietary overlap is expressed as the percentage similarity index (\%PSI). s: summer; w: winter

\begin{tabular}{|c|c|c|c|c|}
\hline \%PSI & 1995 & 1999 & $2000 \mathrm{~s}$ & $2000 w$ \\
\hline \multicolumn{5}{|c|}{ Dietary overlap using 10 prey species categories } \\
\hline 1995 & 100.0 & & & \\
\hline 1999 & 49.6 & 100.0 & & \\
\hline $2000 \mathrm{~s}$ & 24.5 & 41.8 & 100.0 & \\
\hline $2000 w$ & 43.0 & 24.9 & 12.8 & 100.0 \\
\hline \multicolumn{5}{|c|}{ Dietary overlap using 4 prey group categories } \\
\hline 1995 & 100.0 & & & \\
\hline 1999 & 90.5 & 100.0 & & \\
\hline $2000 \mathrm{~s}$ & 87.8 & 80.5 & 100.0 & \\
\hline $2000 \mathrm{w}$ & 92.0 & 92.7 & 87.8 & 100.0 \\
\hline
\end{tabular}


Table 4. Moroteuthis ingens. Discriminant analysis of identifiable hard remains from squid stomach contents, comparing the summers of 1995, 1999 and 2000 (53.9\% of allocated cases correctly classified) and the summer (s) and winter (w) of 2000 (61.5\% of allocated cases correctly classified). GN/P: Gymnoscopelus nicholsi/piabilis, GS: Gymnoscopelus spp.; EC: Electrona carlsbergi, PS: Protomyctophum spp., ST: Stoloteuthis spp.; n: sample size

\begin{tabular}{|c|c|c|c|c|c|c|c|c|}
\hline \multirow[t]{3}{*}{ Allocated group } & \multicolumn{4}{|c|}{ Predicted group membership } & \multirow[t]{3}{*}{$\mathrm{n}$} & \multirow{3}{*}{$\begin{array}{l}\text { Prey species used } \\
\text { in separation }\end{array}$} & \multirow{2}{*}{\multicolumn{2}{|c|}{$\begin{array}{l}\text { Standardised discriminant } \\
\text { function coefficients }\end{array}$}} \\
\hline & \multirow[t]{2}{*}{1995} & \multirow[t]{2}{*}{1999} & \multirow[t]{2}{*}{$2000 s$} & \multirow[t]{2}{*}{$2000 \mathrm{w}$} & & & & \\
\hline & & & & & & & Function 1 & Function 2 \\
\hline 1995 & 33 & 2 & & & 35 & GN/P & 0.614 & 0.790 \\
\hline 1999 & 26 & 10 & 5 & & 41 & GS & 0.813 & -0.583 \\
\hline 2000 & 4 & 4 & 5 & & 13 & & & \\
\hline $2000 \mathrm{~s}$ & & & 11 & 2 & 13 & $\mathrm{EC}$ & 0.676 & \\
\hline $2000 w$ & & & 8 & 5 & 13 & GN/P & -0.894 & \\
\hline & & & & & & PS & 0.352 & \\
\hline & & & & & & $\mathrm{ST}$ & 0.352 & \\
\hline
\end{tabular}

Table 5. Moroteuthis ingens. Total lipid content (\% wet mass) of mantle and digestive gland tissue for each of 4 squid groups. n: sample size

\begin{tabular}{|c|c|c|c|c|}
\hline \multirow{3}{*}{ Squid groups } & \multicolumn{4}{|c|}{ Total lipid content (\% wet mass) } \\
\hline & \multicolumn{2}{|c|}{ Mantle } & \multicolumn{2}{|c|}{ Digestive gland } \\
\hline & $\mathrm{n}$ & Mean \pm SD & $\mathrm{n}$ & Mean $\pm \mathrm{SD}$ \\
\hline $1995 \mathrm{~s}$ & 15 & $1.6 \pm 0.3$ & 15 & $44.7 \pm 15.1$ \\
\hline $1999 \mathrm{~s}$ & 20 & $1.5 \pm 0.2$ & 20 & $35.9 \pm 12.4$ \\
\hline $2000 \mathrm{~s}$ & 10 & $1.4 \pm 0.2$ & 10 & $44.8 \pm 11.2$ \\
\hline $2000 w$ & 5 & $1.3 \pm 0.1$ & 5 & $48.3 \pm 11.9$ \\
\hline
\end{tabular}

Table 6. Moroteuthis ingens. Fatty acids (as \% of total fatty acids) of the mantle tissue of squid from 3 summers (s) and 1 winter $(\mathrm{w})$ period. Values are means $+\mathrm{SD}$. AA: arachidonic acid, DHA: docosahexaenoic acid, DPA: docosapentaenoic acid, SAT: saturated fatty acids, MUFA: monounsaturated fatty acids, PUFA: polyunsaturated fatty acids. n: sample size

\begin{tabular}{|lrrrr|}
\hline Fatty acid & $\begin{array}{r}1995 \mathrm{~s} \\
\mathrm{n}=15\end{array}$ & $\begin{array}{r}1999 \mathrm{~s} \\
\mathrm{n}=20\end{array}$ & $\begin{array}{r}2000 \mathrm{~s} \\
\mathrm{n}=10\end{array}$ & $\begin{array}{c}2000 \mathrm{w} \\
\mathrm{n}=5\end{array}$ \\
\hline $14: 0$ & $1.6 \pm 0.2$ & $1.7 \pm 0.2$ & $1.8 \pm 0.3$ & $1.7 \pm 0.2$ \\
$16: 0$ & $24.8 \pm 1.4$ & $25.8 \pm 2.3$ & $24.6 \pm 2.2$ & $24.8 \pm 0.8$ \\
$18: 0$ & $2.4 \pm 0.3$ & $2.4 \pm 0.3$ & $2.5 \pm 0.1$ & $2.4 \pm 0.1$ \\
$16: 1 \mathrm{n} 7$ & $0.8 \pm 0.3$ & $0.9 \pm 0.1$ & $0.7 \pm 0.2$ & $0.8 \pm 0.1$ \\
$18: 1 \mathrm{n} 9$ & $3.5 \pm 0.6$ & $3.9 \pm 0.7$ & $3.1 \pm 0.3$ & $3.0 \pm 0.2$ \\
$18: 1 \mathrm{n} 7$ & $1.9 \pm 0.5$ & $1.9 \pm 0.2$ & $1.5 \pm 0.2$ & $1.8 \pm 0.2$ \\
$20: 1 \mathrm{n} 9$ & $5.3 \pm 0.3$ & $5.6 \pm 0.4$ & $5.8 \pm 0.7$ & $5.6 \pm 0.2$ \\
$22: 1 \mathrm{n} 11$ & $0.3 \pm 0.1$ & $0.4 \pm 0.3$ & $0.3 \pm 0.0$ & $0.3 \pm 0.0$ \\
$22: 1 \mathrm{n} 9$ & $1.4 \pm 0.2$ & $1.5 \pm 0.3$ & $1.6 \pm 0.2$ & $1.7 \pm 0.1$ \\
$24: 1$ & $0.5 \pm 0.1$ & $0.5 \pm 0.2$ & $0.5 \pm 0.1$ & $0.6 \pm 0.1$ \\
$20: 4 \mathrm{n} 6$ (AA) & $1.8 \pm 0.2$ & $1.9 \pm 0.2$ & $2.0 \pm 0.1$ & $2.0 \pm 0.3$ \\
$20: 5 \mathrm{n} 3$ (EPA) & $13.3 \pm 0.4$ & $13.2 \pm 0.8$ & $13.3 \pm 0.7$ & $13.5 \pm 0.2$ \\
$22: 6 \mathrm{n} 3$ (DHA) & $37.7 \pm 2.0$ & $35.6 \pm 2.9$ & $37.7 \pm 2.3$ & $36.7 \pm 0.8$ \\
$22: 5 \mathrm{n} 3$ (DPA) & $0.5 \pm 0.1$ & $0.5 \pm 0.1$ & $0.5 \pm 0.1$ & $0.6 \pm 0.0$ \\
C23 PUFA & $0.6 \pm 0.3$ & $0.3 \pm 0.4$ & $0.6 \pm 0.4$ & $0.9 \pm 0.2$ \\
Total SAT & $29.6 \pm 1.6$ & $30.8 \pm 2.7$ & $29.7 \pm 2.4$ & $29.7 \pm 0.8$ \\
Total MUFA & $15.0 \pm 1.3$ & $16.1 \pm 1.9$ & $14.6 \pm 1.2$ & $15.1 \pm 0.6$ \\
Total PUFA & $55.1 \pm 2.2$ & $52.8 \pm 2.6$ & $55.5 \pm 2.8$ & $55.0 \pm 0.8$ \\
& & & & \\
\hline
\end{tabular}

same data to distinguish between years: Gymnoscopelus nicholsi/piabilis and Gymnoscopelus spp. (Wilk's lambda $=0.760$, Approx. $F=6.240, p<0.01$ ). Forwardstepwise DA assigned $53.9 \%$ of individuals to the correct summer (53.9\% cross-validated) (Table 4). While $94 \%$ of individuals from the 1995 summer were assigned to the correct year, only 24 and $39 \%$ of individuals were correctly assigned to the 1999 and 2000 summers, respectively. This largely reflects the fact that very few 1995 summer squid had consumed either G. nicholsi or Gymnoscopelus spp.; those that had were incorrectly assigned to the 2000 summer. In contrast, 1999 and 2000 summer squid that had not consumed G. nicholsi and Gymnoscopelus spp. were incorrectly assigned to the 1995 summer. Squid that had consumed only G. nicholsi/piabilis were assigned to the 1999 summer, whereas squid that had consumed Gymnoscopelus spp. and perhaps also G. nicholsi/ piabilis were assigned to the 2000 summer.

Complete linear canonical DA indicated that the diet of Moroteuthis ingens did not vary between the 2000 summer and winter (Wilk's lambda $=0.830$, Approx. $F=1.073, \mathrm{p}<0.5)$, in contrast to results obtained for the \%PSI. Complete linear canonical DA assigned 61.5\% of squid to the correct season (26.9\% cross-validated) (Table 4). Forward-stepwise DA could not be used to compare 2000 summer and winter stomach contents data.

\section{Lipid and fatty acid analyses}

Mantle tissue was low in lipid, with mean contents between $1.3 \pm 0.1 \%$ wet mass (2000 winter) and $1.6 \pm$ $0.3 \%$ wet mass (1995 summer) (Table 5). Digestive gland tissue was lipid-rich, with a content between $35.9 \pm 12.4 \%$ wet mass (1999 summer) and $48.3 \pm$ $11.9 \%$ wet mass (2000 winter) (Table 5). No significant 
Table 7. Moroteuthis ingens. Fatty acids (as \% of total fatty acids) of the digestive gland of squid from 3 summers and 1 winter period. Values are means $\pm \mathrm{SD}$. AA: arachidonic acid, DHA: docosahexaenoic acid, DPA: docosapentaenoic acid, SAT: saturated fatty acids, MUFA: monounsaturated fatty acids, PUFA: polyunsaturated fatty acids. n: sample size

\begin{tabular}{|c|c|c|c|c|}
\hline Fatty acid & $\begin{array}{c}1995 \mathrm{~s} \\
\mathrm{n}=15\end{array}$ & $\begin{array}{l}1999 \mathrm{~s} \\
\mathrm{n}=20\end{array}$ & $\begin{array}{l}2000 \mathrm{~s} \\
\mathrm{n}=10\end{array}$ & $\begin{array}{c}2000 \mathrm{w} \\
\mathrm{n}=5\end{array}$ \\
\hline $14: 0$ & $3.1 \pm 0.6$ & $3.1 \pm 0.6$ & $3.1 \pm 0.3$ & $3.5 \pm 0.2$ \\
\hline $16: 0$ & $15.6 \pm 1.8$ & $14.8 \pm 1.4$ & $16.2 \pm 1.9$ & $14.7 \pm 1.0$ \\
\hline $18: 0$ & $3.1 \pm 0.5$ & $3.6 \pm 0.7$ & $4.0 \pm 0.5$ & $3.2 \pm 0.3$ \\
\hline br17:1 & $0.5 \pm 0.2$ & $0.6 \pm 0.2$ & $0.5 \pm 0.1$ & $0.4 \pm 0.1$ \\
\hline $16: 1 \mathrm{n} 7$ & $4.7 \pm 1.1$ & $3.9 \pm 1.2$ & $4.0 \pm 0.7$ & $4.3 \pm 0.4$ \\
\hline 18:1n9 & $23.2 \pm 2.6$ & $25.6 \pm 4.4$ & $21.5 \pm 2.3$ & $20.5 \pm 1.6$ \\
\hline $18: 1 \mathrm{n} 7$ & $4.2 \pm 0.7$ & $5.0 \pm 0.7$ & $3.3 \pm 1.1$ & $4.7 \pm 0.5$ \\
\hline 18:1n5 & $0.6 \pm 0.1$ & $0.7 \pm 0.1$ & $0.6 \pm 0.1$ & $0.7 \pm 0.0$ \\
\hline 20:1n9 & $8.9 \pm 1.7$ & $11.5 \pm 2.3$ & $10.8 \pm 3.2$ & $11.1 \pm 1.2$ \\
\hline $20: 1 \mathrm{n} 7$ & $0.7 \pm 0.1$ & $0.7 \pm 0.1$ & $0.6 \pm 0.1$ & $0.8 \pm 0.1$ \\
\hline $22: 1 n 11$ & $5.3 \pm 1.5$ & $5.7 \pm 2.8$ & $5.3 \pm 1.5$ & $5.4 \pm 0.6$ \\
\hline 22:1n9 & $2.8 \pm 0.8$ & $2.3 \pm 0.6$ & $2.4 \pm 0.6$ & $2.8 \pm 0.2$ \\
\hline $24: 1$ & $3.2 \pm 1.4$ & $2.9 \pm 1.1$ & $2.7 \pm 1.4$ & $3.1 \pm 1.1$ \\
\hline $18: 2 \mathrm{n} 6$ & $1.1 \pm 0.2$ & $1.1 \pm 0.2$ & $1.0 \pm 0.2$ & $1.0 \pm 0.1$ \\
\hline $20: 4 n 6$ (AA) & $0.6 \pm 0.1$ & $0.7 \pm 0.2$ & $0.8 \pm 0.1$ & $0.7 \pm 0.1$ \\
\hline 20:5n3 (EPA) & $5.5 \pm 0.9$ & $4.0 \pm 1.3$ & $5.8 \pm 1.5$ & $5.7 \pm 0.6$ \\
\hline $20: 4 n 3$ & $0.7 \pm 0.1$ & $0.6 \pm 0.1$ & $0.8 \pm 0.2$ & $0.7 \pm 0.0$ \\
\hline 22:6n3 (DHA) & $9.9 \pm 2.2$ & $7.1 \pm 2.7$ & $10.6 \pm 2.7$ & $10.0 \pm 1.7$ \\
\hline $22: 5 n 3$ (DPA) & $0.8 \pm 0.1$ & $0.7 \pm 0.2$ & $0.9 \pm 0.2$ & $1.0 \pm 0.1$ \\
\hline Total SAT & $22.7 \pm 2.2$ & $22.7 \pm 2.1$ & $24.3 \pm 2.2$ & $22.3 \pm 1.1$ \\
\hline Total MUFA & $55.0 \pm 3.6$ & $60.2 \pm 5.5$ & $52.2 \pm 4.6$ & $54.9 \pm 3.5$ \\
\hline Total PUFA & $21.1 \pm 3.2$ & $16.2 \pm 4.4$ & $22.4 \pm 4.8$ & $21.7 \pm 2.4$ \\
\hline
\end{tabular}

differences in mantle or digestive gland total lipid content were observed between groups.

Mantle tissue is characterised by large amounts of polyunsaturated fatty acids (PUFAs): principally docosahexaenoic acid (DHA, 22:6n3), comprising between $35.6 \pm 2.9 \%$ and $37.7 \pm 2.3 \%$ of total fatty acids, and eicosapentaenoic acid (EPA, 20:5n3), comprising between $13.2 \pm 0.8 \%$ and $13.5 \pm 0.2 \%$ of total fatty acids (Table 6 ). No other PUFA comprised more than $2.5 \%$ of the total fatty acids. Total PUFA values varied from
$52.8 \pm 2.6 \%$ to $55.5 \pm 2.9 \%$ of total fatty acids, between the 1999 summer and 2000 summer respectively. Total saturated fatty acid (SAT) values ranged from $29.6 \pm$ $1.6 \%$ of total fatty acids in 2000 winter females, to $30.8 \pm 2.7 \%$ of total fatty acids in 1999 summer. SATs were largely comprised of 16:0. Monounsaturated fatty acids (MUFAs) were the least abundant class of fatty acids at $14.6 \pm 1.2 \%$ to $16.1 \pm 1.9 \%$ of total fatty acids. 18:1n9 and 20:1n9 were major MUFAs.

Digestive gland fatty acid profiles were dominated by MUFAs, which contributed from $52.2 \pm 4.6 \%$ to $60.2 \pm 5.6 \%$ of total fatty acids, between the 2000 summer and 1999 summer respectively (Table 7). MUFAs were largely comprised of $18: 1 \mathrm{n} 9$ at $20.5 \pm 1.6 \%$ to $25.6 \pm 4.4 \%$ of total fatty acids). The major SAT was $16: 0$, as observed in mantle tissue. Total SAT values ranged from $22.3 \pm 1.1 \%$ to $24.3 \pm 2.2 \%$ of total fatty acids (between 2000 winter and 2000 summer, respectively), and similar values of total PUFA were observed. PUFA levels were lowest in the 1999 summer $(16.2 \pm 4.4 \%$ of total fatty acids $)$ and highest in the 2000 summer $(22.4 \pm 4.8 \%$ of total fatty acids $)$, and were comprised largely of DHA and EPA.

\section{Interannual and seasonal comparisons of fatty acid data}

Forward-stepwise DA of digestive gland fatty acid data provided firm evidence that dietary intake varied between summers (Wilks' lambda $=0.161$, Approx. $F=11.324$, p < 0.01), with $93.3 \%$ cases correctly assigned (88.9\% cross-validated) using only 5 fatty acid variables (Table 8). The first discriminant function accounted for $79.9 \%$ of variability in the data, and clearly separated 1999 summer squid from the 1995 and 2000 summer squid (Fig. 4). This function can be interpreted as a contrast between proportions of 18:1n7 and proportions of DHA (Table 8),

Table 8. Moroteuthis ingens. Discriminant analysis of digestive gland fatty acid data comparing the summers of 1995,1999 and 2000 (93.3\% of allocated cases correctly classified) and the summer (s) and winter (w) of $2000(100 \%$ of allocated cases classified correctly). AA: arachidonic acid, DHA: docosahexaenoic acid; n: sample size

\begin{tabular}{|c|c|c|c|c|c|c|c|c|}
\hline \multirow[t]{2}{*}{ Allocated group } & \multicolumn{4}{|c|}{ Predicted group membership } & \multirow[t]{2}{*}{$\mathrm{n}$} & \multirow{2}{*}{$\begin{array}{l}\text { Fatty acids used } \\
\text { in separation }\end{array}$} & \multicolumn{2}{|c|}{$\begin{array}{l}\text { Standardised discriminant } \\
\text { function coefficients }\end{array}$} \\
\hline & 1995 & 1999 & $2000 \mathrm{~s}$ & 2000w & & & $\begin{array}{r}\text { function } \\
\text { Function } 1\end{array}$ & $\begin{array}{l}\text { fficients } \\
\text { Function } 2\end{array}$ \\
\hline 1995 & 14 & & 1 & & 15 & $14: 0$ & 1.787 & -0.344 \\
\hline 1999 & 1 & 19 & & & 20 & 18:0 & 0.59 & -1.321 \\
\hline \multirow[t]{3}{*}{2000} & 1 & & 9 & & 10 & $18: 1 \mathrm{n} 7$ & -2.242 & 2.242 \\
\hline & & & & & & $20: 4 \mathrm{n} 6$ (AA) & -1.637 & -1.816 \\
\hline & & & & & & 22:6n3 (DHA) & 1.749 & 1.245 \\
\hline $2000 \mathrm{~s}$ & & & 10 & & 10 & 20:1n9 & -1.036 & \\
\hline $2000 w$ & & & & 5 & 5 & $20: 1 \mathrm{n} 7$ & 1.689 & \\
\hline
\end{tabular}




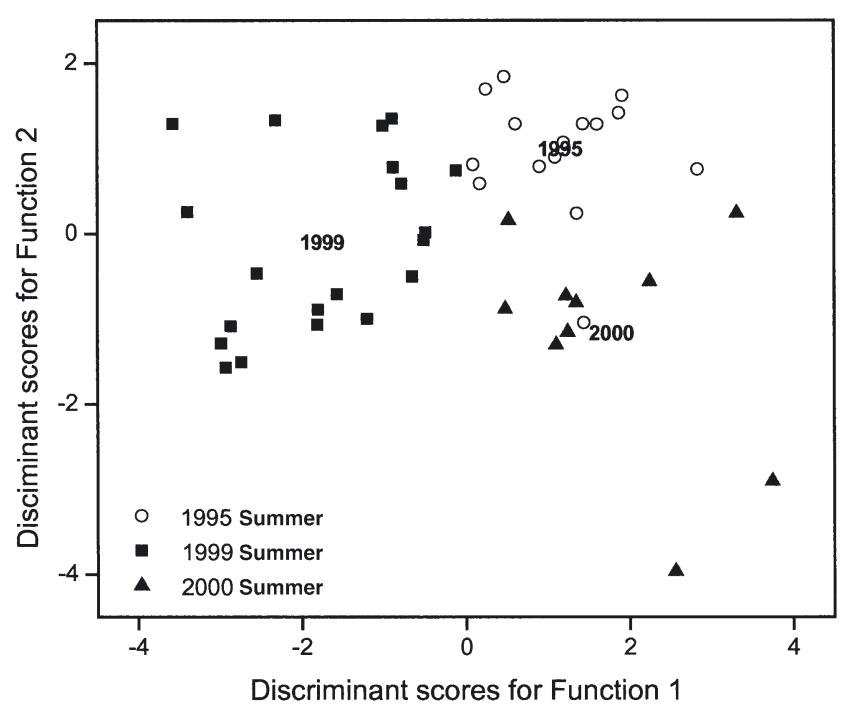

Fig. 4. Moroteuthis ingens. Discriminant scores of fatty acid data $\left(\mathrm{mg} \mathrm{g}^{-1}\right.$ ) from the digestive gland. Year-group labels in the figure are positioned over respective group centroids

with the 1999 summer squid having significantly higher levels of 18:1n7 than 1995 or 2000 summer squid $(F=16.46, \mathrm{p}<0.01)$ and significantly lower levels of DHA than 1995 or 2000 summer squid $(F=8.44$, $\mathrm{p}<0.01$ ) (Table 7). Sum values of MUFA and PUFA were significantly different between summers (MUFA: $F=6.19, \mathrm{p}<0.01$; PUFA: $F=5.68, \mathrm{p}<0.01$ ). The interannual trends in 18:1n7 and DHA are reflected in sum MUFA and PUFA values; that is, mean MUFA levels were highest during the 1999 summer, whereas mean PUFA abundance was lowest during this season (Table 7).

The second discriminant function accounted for the remaining $21.1 \%$ of variability in the fatty acid data, and separated the 1995 summer squid from the 2000 summer squid (Fig. 4). This function can be interpreted as a contrast between proportions of 18:0 and 18:1n 7 . Proportions of 18:0 were significantly different between 1995 and 2000 summer squid $(F=5.33, \mathrm{p}<0.01)$ (Table 7), and squid with high levels of 18:0 were assigned to the 2000 summer (Table 8). Proportions of 18:1n7 were significantly larger in 1995 summer squid compared to 2000 summer squid $(F=16.46, \mathrm{p}<0.01)$ (Table 7) and squid with higher 18:1n7 levels were assigned to the 1995 summer (Table 8).

Fatty acid composition of the digestive gland varied between the 2000 summer and winter (forward-stepwise DA; Wilks' lambda $=0.287$, Approx. $F=14.902$, $\mathrm{p}<0.01$ ). Two MUFAs, 20:1n9 and 20:1n7, were used to distinguish the 2000 summer from the 2000 winter with $100 \%$ of cases correctly assigned $(86.7 \%$ crossvalidated) (Table 8). Hence fatty acid data supports findings from the \%PSI that a considerable shift in diet occurred between the 2000 summer and 2000 winter.

Interannual variations were also observed in the fatty acid composition of mantle tissue using complete linear canonical DA (Wilks' lambda $=0.164$, Approx. $F=2.741, \mathrm{p}<0.01$ ). Forward-stepwise DA indicated that $18: 1 \mathrm{n} 7,20: 1 \mathrm{n} 9$ and DHA were largely responsible for interannual variations in mantle composition. These 3 fatty acid discriminators correctly assigned $75.6 \%$ of individuals ( $73.3 \%$ cross-validated). The first discriminant function was largely a contrast between proportions of $18: 1 \mathrm{n} 7$ and 20:1n9, where individuals with lower proportions of $18: 1 \mathrm{n} 7$ and higher proportions of $20: 1 \mathrm{n} 9$ were allocated to the 2000 summer (Table 9). The second discriminant function was a contrast between proportions of $18: 1 \mathrm{n} 7$ and $\mathrm{DHA}_{i}$ individuals with higher proportions of 18:1n7 were assigned to the 1999 summer whereas individuals with higher proportions of DHA were assigned to the 1995 summer (Table 9).

Complete linear canonical DA indicated that there was little seasonal variation in the fatty acid composition of mantle tissue between the 2000 summer and winter (Wilks' lambda $=0.200$, Approx. $F=2.220$, $\mathrm{p}<0.5$ ). Forward-stepwise DA functions could not be constructed to discriminate between the 2000 summer and 2000 winter using mantle fatty acid profiles.

\section{DISCUSSION}

Comparisons of stomach content and digestive gland fatty acid data for Moroteuthis ingens have enabled us

Table 9. Moroteuthis ingens. Discriminant analysis of mantle fatty acid data, comparing the summers of 1995, 1999 and 2000 ( $75.6 \%$ of allocated cases correctly classified). DHA: docosahexaenoic acid; $\mathrm{n}$ : sample size

\begin{tabular}{|c|c|c|c|c|c|c|c|}
\hline \multirow[t]{2}{*}{ Allocated group } & \multicolumn{3}{|c|}{ Predicted group membership } & \multirow[t]{2}{*}{$\mathrm{n}$} & \multirow{2}{*}{$\begin{array}{l}\text { Fatty acids used } \\
\text { in separation }\end{array}$} & \multirow{2}{*}{\multicolumn{2}{|c|}{$\begin{array}{l}\text { Standardised discriminant } \\
\text { function coefficients }\end{array}$}} \\
\hline & 1995 & 1999 & 2000 & & & & \\
\hline 1995 & 9 & 5 & 1 & 15 & $18: 1 \mathrm{n} 7$ & 7.039 & -1.675 \\
\hline 1999 & 1 & 17 & 2 & 20 & $20: 1 n 9$ & -9.242 & 0.657 \\
\hline 2000 & & 2 & 8 & 10 & 22:6n3 (DHA) & 2.541 & 1.873 \\
\hline
\end{tabular}


to draw 3 main conclusions regarding temporal variations in diet composition at Macquarie Island. Firstly, interannual and seasonal comparisons of digestive gland fatty acids reveal significant differences in fatty acid composition between collection periods, indicating that the dietary intake of lipid by $M$. ingens varied between 3 summers and also between a consecutive summer and winter. Secondly, stomach contents provide reliable information on the broad prey spectrum of $M$. ingens, the diversity of prey consumed by an individual, and an indication of which prey species may be responsible for temporal variations in dietary lipid uptake. Thirdly, neither technique should be used in isolation to determine interannual and seasonal variations in the diet of $M$. ingens.

\section{Interannual and seasonal variations in diet}

Based on the findings of previous studies, we have assumed that lipid stored in the digestive gland of Moroteuthis ingens is of strictly dietary origin (Blanchier \& Boucaud-Camou 1984, Abolmasova et al. 1990, Clarke et al. 1994, Semmens 1998, Phillips et al. 2001). There was sufficient between-year variation in the fatty acid profiles of digestive glands collected over 3 summers to assign $>93 \%$ of individuals to the correct summer. That is, dietary intake of fatty acids by $M$. ingens differed considerably between the summers of 1995, 1999 and 2000, most likely as a result of changes in the proportions of available prey over the study period (Fig. 4).

The shift in dietary composition during the 1999 summer relative to other summer periods, as indicated by significantly higher levels of 18:1n7 and MUFA, may have resulted from an increased intake of certain myctophid species, during this period. These fish are unique in that their lipids are characterised by large amounts of MUFA as opposed to PUFA (Saito \& Murata 1998). Even within the myctophid group, some species, such as Gymnoscopelus nicholsi, are particularly rich in both lipid and MUFA (Phleger et al. 1999, Lea et al. 2002). Lea et al. (2002) noted that levels of 18:1n7 were particularly elevated in G. nicholsi compared with other myctophid species, and that levels of DHA were relatively low. This pattern was also generally reflected in myctophid species studied by Phleger et al. (1999). The discriminators 18:1n7 and DHA were both largely responsible for separating 1999 summer squid from 1995 and 2000 summer squid (Table 8). G. nicholsi/piabilis and Gymnoscopelus spp. were the only prey variables incorporated into forward-stepwise DA of stomach contents to distinguish between year groups. Fatty acid profiles therefore indicate that many otoliths identified in 1999 stomachs are representative of G. nicholsi rather than G. piabilis. With this assumption, comparisons of fatty acid and stomach contents analyses indicate that interannual variations in the diet of Moroteuthis ingens were largely due to an increased consumption of G. nicholsi during the 1999 summer relative to other years.

Interannual variations in the availability of myctophids have affected other marine predators in the Southern Ocean. The diet of the king penguin has been subject to interannual variations in composition during summer, largely dependent on the scarcity or abundance of key myctophid species such as Krefftichthys anderssoni (Olsson \& North 1997, Rodhouse et al. 1998). The proportions of myctophids in the diet of the Patagonian toothfish has also varied on an interannual basis at Macquarie Island (Goldsworthy et al. 2002), although no information is available for individual myctophid species. Larger amounts of PUFA in the digestive gland of Moroteuthis ingens during the 1995 and 2000 summers may be related to higher dietary proportions of non-myctophid fish, such as Bathylagus antarcticus and Paradiplospinus gracilis.

The comparison of several oceanographic parameters suggests that environmental conditions around Macquarie Island were different during the summer of 1999, relative to the summers of 1995 and 2000 (Table 10). The 1999 summer was characterised by warmer sea-surface temperatures around the island and a substantial decrease in primary production. Thus, environmental fluctuations have feasibly underpinned temporal variations in prey availability over the study period. Goldsworthy et al. (2001b) suggest that cooler sea-surface temperatures (SST) may be related to increased primary production at Macquarie Island. While the affects of decreased primary production and warmer sea surface temperatures on nektonic fish and squid communities are presently unknown, DA of digestive gland fatty acid profiles and stomach contents data suggest that such environmental fluctuations have had an effect on the dietary structure of M. ingens.

Table 10. Oceanographic parameters around Macquarie Island recorded over the study period. Data are from Goldsworthy et al. (2001b). SST: sea surface temperature

\begin{tabular}{|c|c|c|}
\hline Season & $\begin{array}{l}\text { Mean summer SST } \\
\text { relative to the } \\
1981-2000 \text { mean }\end{array}$ & $\begin{array}{l}\text { Ocean colour } \\
\text { (chlorophyll a) data }\end{array}$ \\
\hline Summer 1995 & Cooler & No data available \\
\hline Summer 1999 & Warmer & $\begin{array}{l}\text { No significant local } \\
\text { primary production }\end{array}$ \\
\hline Summer 2000 & Cooler & $\begin{array}{l}\text { Homogenous local } \\
\text { primary production }\end{array}$ \\
\hline
\end{tabular}


Analysis of digestive gland fatty acid profiles of Moroteuthis ingens provides evidence for a highly significant switch in prey between the summer and winter of 2000. Two MUFAs (20:1n9 and 20:1n7) were required to assign individuals to the summer or winter period with $100 \%$ accuracy. The 20:1 MUFAs are particularly important components of myctophid MUFA content (Saito \& Murata 1998). While triacylglycerol (TAG) is the major lipid class of many myctophid species, some species contain wax ester (WE) as their major lipid class (Saito \& Murata 1996, Phleger et al. 1999). The relative proportions of MUFA vary between these groups of myctophids, with several TAG-rich myctophid species (Gymnoscopelus opisthopterus, Gymnoscopelus nicholsi and Electrona carlsbergi) containing much larger amounts of 20:1 MUFAs than the WE-rich myctophids Gymnoscopelus braueri and Krefftichthys anderssoni (Phleger et al. 1999). The amounts of 20:1n9 and 20:1n7 were both significantly higher in the digestive gland of $M$. ingens during winter compared to summer $(p<0.05$ and $p<0.01$, respectively). Comparisons with stomach contents data suggest that increased 20:1n9 and 20:1n7 during winter may reflect a switch of dominant prey species from WE-rich, species such as $K$. anderssoni, during summer to TAG-rich species, such as E. carlsbergi, during winter.

Krefftichthys anderssoni was absent from the diet of Moroteuthis ingens during the 2000 winter, whereas Electrona carlsbergi was more abundant in terms of $\mathrm{N}$, $\% \mathrm{NI}$ and \%FO compared to the 2000 summer. These findings support evidence from the stomach contents of king penguins that $E$. carlsbergi replaces $K$. anderssoni as the dominant prey item of this predator during winter at Macquarie Island (Hindell 1988). Other analyses of seasonal variations in stomach contents between the 2000 summer and winter are ambiguous; on the one hand, the \%PSI suggests that there is little overlap in diet, while DA of stomach contents data suggests that diet did not vary over this period.

\section{A comparison of methods}

This study has confirmed that while fatty acid analysis complements stomach contents analysis, neither technique should be used in isolation to assess temporal variations in diet. We have not been able to incorporate fatty acid data of prey species into our analyses. Samples of myctophids are typically difficult to access (Lea et al. 2002), particularly as by-catch from commercial trawlers, and have not been collected as part of this study. Although published fatty acid profiles are available for some Southern Ocean myctophid species (Reinhardt \& Van Vleet 1986, Phleger et al. 1997,
Raclot et al. 1998, Phleger et al. 1999, Lea et al. 2002), data are only available for 2 species from Macquarie Island; Electrona antarctica and Gymnoscopelus fraseri (Lea et al. 2002). The fatty acid profiles of myctophids are prone to considerable spatial variations (Phleger et al. 1997, Lea et al. 2002), and we did not consider it valid to include data from geographically distant sites into an analysis of temporal variation of the lipids of Moroteuthis ingens at Macquarie Island. Furthermore, almost no fatty acid data exists for the cephalopod prey of $M$. ingens and, without further identification of crustacean prey, no crustacean fatty acid data could be included in temporal analyses. Fatty acid data have clearly shown that the diet of $M$. ingens at Macquarie Island has varied on both an interannual and seasonal basis during the study period. However, due to the current paucity of data for potential prey, fatty acid data provide very little information on the relative proportions of individual prey species in the diet at a given time.

In contrast, while stomach contents provide reliable information on the species composition of the diet, temporal variations are much more difficult to interpret in these data compared to fatty acid data. Although Moroteuthis ingens was shown to consume a broad range of prey (Table 2), the prey-diversity index for individual stomachs was very low; those stomachs with identifiable prey remains contained a mean of 2.5 prey species, and almost half of these stomachs contained only 1 prey species (Fig. 2). Thus, our data contained a large amount of within-group variation, and it was necessary to conduct between-group comparisons with few prey variables. For example, only 4 prey species were consistently present in the diet over the study period, i. e. the myctophids Electrona carlsbergi, Gymnoscopelus nicholsi/piabilis and Protomyctophum spp. and the cephalopod Stoloteuthis sp. Contrasting findings from the \%PSI and DA of stomach contents may be largely due to methods used to reduce the stomach contents dataset-by either grouping prey or excluding prey species from analyses according to arbitrary selection criteria - so that groups could be more easily compared.

Indices of prey abundance used in stomach contents analyses must be treated with caution: indices such as $\%$ NI overestimate the importance of small prey items that are consumed in large numbers, e.g. Krefftichthys anderssoni and Electrona carlsbergi (Hyslop 1980). This source of error is compounded by the fact that squid may often reject the heads of larger fish (Collins \& Pierce 1996). This may strongly bias against the larger prey species, but rarely affect the small species. Based on the absence of otoliths and eye lenses combined with large amounts of fish remains, we suspected that heads of fish had been rejected by up to 
$19 \%$ of individual squid. One final problem that obstructed the temporal analyses in the diet of Moroteuthis ingens from stomach contents data is that we were unable to include estimates of crustacean remains as a proportion of the diet. On most occasions, the number of crustaceans in a sample could not be determined from exoskeleton remains.

\section{Prey size of Moroteuthis ingens}

Individuals of Moroteuthis ingens that were collected at depths between $250 \mathrm{~m}$ and $1200 \mathrm{~m}$ had consumed a large size-range of fish prey, including the larger cohort of a number of species such as Electrona subaspera, Gymnoscopelus fraseri/bolini, Gymnoscopelus nicholsi/piabilis and Bathylagus antarcticus (Fig. 3). Interestingly, however, $M$. ingens had only consumed specimens of Krefftichthys anderssoni, Electrona antarctica, Electrona carlsbergi and Gymnoscopelus braueri that were within the size-range of juveniles (Hulley 1990). Comparisons with the SL of other fish prey suggest that this was due to the absence of shoals of adult fish around Macquarie Island during the study period, rather than size discriminiation by the predator.

While Moroteuthis ingens can prey on relatively large fish, the size of cephalopod prey is a limiting constraint and only small individuals are eaten. Although LRL of cephalopod beaks were not measured during this study, all beaks were estimated to have a crest length of $<3 \mathrm{~mm}$ and thus derive from very small individuals. Similarly, Collins \& Pierce (1996) found that individual squid of the species Loligo forbesi could only consume squid much smaller than themselves.

\section{Mantle fatty acid profiles}

We have observed some interannual variation in the fatty acid composition of mantle tissue; for example, trends in the proportions of 18:1n7 and DHA observed in the digestive gland during the 1999 summer were also seen in mantle tissue. However, fatty acids incorporated into largely fulfil specific requirements, and selective uptake of fatty acids by mantle tissue will lead to a degree of homogeneity in mantle tissue fatty acid composition over time. That is, while temporal variations in dietary uptake of fatty acids may have some influence on the fatty acid composition of mantle tissue, other processes (e.g. modification or biosynthesis of fatty acids) may also independently account for mantle fatty acid composition. Therefore, mantle tissue is not affected by temporal variations in dietary lipid uptake to the some extent as digestive gland tissue, and fatty acid profiles of the former cannot be so easily related to temporal variations in the environment of Moroteuthis ingens.

\section{Conclusions}

We have detected interannual and seasonal variation in the diet of Moroteuthis ingens at Macquarie Island using a combination of stomach contents and fatty acid analyses. A considerable shift in dietary lipid uptake was observed during the 1999 summer relative to the 1995 and 2000 summers, and both fatty acid and stomach contents data indicate that this was due to an increased consumption of Gymnoscopelus nicholsi at this time. Comparisons with oceanographic data confirm that conditions around the island differed during the 1999 summer relative to other summers, and changing oceanographic conditions may have affected prey distribution and food availability to $M$. ingens. Fatty acid and stomach content analyses suggest that, during the 2000 winter, Electrona carlsbergi replaced Krefftichthys anderssoni as an important prey species, as observed for other marine predators in the Southern Ocean.

Acknowledgements. K.L.P. is a recipient of a Tasmanian Strategic Research Scholarship. We thank C. Sands for assisting with squid dissections, J. Kitchener for identifying crustacean remains, D. Williams for his assistance with otolith identifications and T. van Ommen for assisting with Fig. 1. M. Haddon and S. Wotherspoon provided statistical advice, and S. Rintoul assisted with the interpretation of oceanographic data. Many thanks to the crew and skipper aboard 'Austral Leader' and to observers from the Australian Fisheries Management Authority. B. Mooney and D. Holdsworth managed the CSIRO GC and GC-MS facilities, respectively. Four anonymous reviewers made constructive comments on a previous version of this manuscript. This work was supported in part by an Australian Research Council large grant (no. A19933031) awarded to G.D.J.

\section{LITERATURE CITED}

Abolmasova GI, Shul'man GY, Shchepkina AM, Dzhiganshin GF (1990) Content of dry matter in the liver of the squid Stenoteuthis pteropus in the eastern Atlantic Ocean as an index of trophicity. Oceanology 30:359-362

Ackman RG (1980) Fish lipids. Part 1. In: Connell JJ (ed) Advances in fish science and technology. Fishing News Books, Oxford, p 86-103

Blanchier B, Boucaud-Camou E (1984) Lipids in the digestive gland and the gonad of immature and mature Sepia officinalis (Mollusca: Cephalopoda). Mar Biol 80:39-43

Bligh EG, Dyer WJ (1959) A rapid method of total lipid extraction and purification. Can J Biochem Physiol 37:911-917

Cherel Y, Weimerskirch H (1999) Spawning cycle of onychoteuthid squids in the southern Indian Ocean: new information from seabird predators. Mar Ecol Prog Ser 188:93-104 
Clarke A, Rodhouse PG, Gore DJ (1994) Biochemical composition in relation to the energetics of growth and sexual maturation in the ommastrephid squid Illex argentinus. Phil Trans R Soc Lond Ser B Biol Sci 344:201-212

Clarke MR (1983) Cephalopod biomass: estimation from predation. Mem Natl Mus Vic 44:95-107

Clarke MR (1986) A handbook for the identification of cephalopod beaks. Clarendon Press, Oxford

Clarke MR (1996) The role of cephalopods in the world's oceans: general conclusions and the future. Phil Trans R Soc Lond Ser B Biol Sci 351:1105-1112

Collins MA, Pierce GJ (1996) Size selectivity in the diet of Loligo forbesi (Cephalopoda: Loliginidae). J Mar Biol Assoc UK 76:1081-1090

Cripps GC, Watkins JL, Hill HJ, Atkinson A (1999) Fatty acid content of Antarctic krill Euphausia superba at South Georgia relate to regional populations and variations in diet. Mar Ecol Prog Ser 181:177-188

Filin A, Gorchinsky K, Kiseleva MI (1991) Biomass of myctophids in the Atlantic sector of the Southern Ocean as estimated by acoustic surveys. CCAMLR Selected Scientific Papers, Hobart, SC-CAMLR-SSP/7:417-431

Gaskett A, Bulman C, He X, Goldsworthy SD (2001) Diet composition and guild structure of mesopelagic and bathypelagic fishes near Macquarie Island, Australia. NZ J Mar Freshw Res 35:469-476

Goldsworthy SD, He X, Tuck GN, Lewis M, Williams R (2001a) Trophic interactions between the Patagonian toothfish, its fishery, and seals and seabirds around Macquarie Island. Mar Ecol Prog Ser 218:283-302

Goldsworthy SD, He X, Furlani D, Moore T and 6 others (2001b) Physical and biological oceanography. In: He X, Furlani D (eds) Ecologically sustainable development of the fishery for Patagonian toothfish (Disosstichus eleginoides) around Macquarie Island: population parameters, population assessment and ecological interactions. CSIRO Marine Research, Australian Antarctic Division and Austral Fisheries Pty Ltd, Hobart, p 28-58

Goldsworthy SD, Lewis M, Williams R, He X, Young JW, van den Hoff J (2002) Diet of Patagonian toothfish (Dissostichus eleginoides) around Macquarie Island, South Pacific Ocean. Mar Freshw Res 53:49-57

Graeve M, Kattner G, Hagen W (1994) Diet-induced changes in the fatty acid composition of Arctic herbivorous copepods: experimental evidence of trophic markers. J Exp Mar Biol Ecol 182:97-110

Hindell MA (1988) The diet of the king penguin Aptenodytes patagonicus at Macquarie Island. Ibis 130:193-203

Hulley P (1990) Family Myctophidae, lanternfishes. In: Gon O, Heemstra PC (eds) Fishes of the Southern Ocean. JLB Smith Institute of Ichthyology, Grahamstown, p 146-178

Hyslop EJ (1980) Stomach contents analysis - a review of methods and their application. J Fish Biol 17:411-429

Jackson GD, Mladenov PV (1994) Terminal spawning in the deepwater squid Moroteuthis ingens (Cephalopoda: Onychoteuthidae). J Zool 234:189-201

Jackson GD, George MJA, Buxton NG (1998a) Distribution and abundance of the squid Moroteuthis ingens (Cephalopoda: Onychoteuthidae) in the Falkland Islands region of the South Atlantic. Polar Biol 20:161-169

Jackson GD, McKinnon JF, Lalas C, Ardern R, Buxton N (1998b) Food spectrum of the deepwater squid Moroteuthis ingens (Cephalopoda: Onychoteuthidae) in New Zealand waters. Polar Biol 20:56-65

Kock K (1987) Marine consumers: fish and squid. Environ Int 13:37-45

Kozlov AN (1995) A review of the trophic role of mesopelagic fish of the family Myctophidae in the Southern Ocean ecosystem. CCAMLR Sci 2:71-77

Lea M, Nichols PD, Wilson G (2002) Fatty acid composition of lipid-rich myctophids and mackerel icefish (Champsocephalus gunnari) - Southern Ocean food-web implications. Polar Biol 25:843-854

Lipinski MR (1979) Universal maturity scale for the commercially important squids. The results of maturity classification of the Illex illecebrosus (Le Sueur, 1821) population for the years 1973-1977. Res Doc Int Comm Northwest Atl Fish (ICNAF), 79/II/38 (Serial No. 5364), p 1-490

Lipinski MR, Linkowski TB (1986) Some aspects of the biology of the squid Moroteuthis ingens (Onychoteuthidae) from New Zealand waters. Rep Sea Fish Inst 21:97-105

Lubimova T (1985) Results of Soviet investigations of the distribution and ecology of pelagic squids (Oegopsida) in the Southern Ocean. CCAMLR, Hobart, SC-CAMLR-IV/BG 18:79-111

Mourente G, Tocher D (1993) The effects of weaning on to a dry pellet diet on brain lipid and fatty acid compositions in post-larval gilthead sea bream (Sparus aurata L.). Comp Biochem Physiol 104A: 605-611

Navarro JC, Villanueva R (2000) Lipid and fatty acid composition of early stages of cephalopods: an approach to their lipid requirements. Aquaculture 183:161-177

Nesis K (1987) Cephalopods of the world: squids, cuttlefishes, octopuses and allies. Tropical Fish Hobbyist Publications, Neptune City, NJ

Okutani T (1994) The importance of the Southern Ocean cephalopod fauna. Antarct Sci 6:135

Olsson O, North AW (1997) Diet of the king penguin Aptenodytes patagonicus during three summers at South Georgia. Ibis 139:504-512

Pakhomov EA, Perissinotto R, McQuaid CD (1996) Prey composition and daily rations of myctophid fishes in the Southern Ocean. Mar Ecol Prog Ser 134:1-14

Phillips KL, Jackson G, Nichols PD (2001) Predation on myctophids by the squid Moroteuthis ingens around Macquarie and Heard Islands: stomach contents and fatty acid analyses. Mar Ecol Prog Ser 215:179-189

Phillips KL, Nichols PD, Jackson GD (2002) Lipid and fatty acid composition of the mantle and digestive gland of four Southern Ocean squid species: implications for food-web studies. Antarct Sci 14:212-220

Phleger CF, Nichols PD, Virtue P (1997) The lipid, fatty acid and fatty alcohol composition of the myctophid fish Electrona antarcticus: high level of wax esters and food-chain implications. Antarct Sci 9:258-265

Phleger CF, Nelson MM, Mooney BD, Nichols PD (1999) Wax esters versus triacylglycerols in myctophid fishes from the Southern Ocean. Antarct Sci 11:437-445

Piatkowski U, Pierce GJ, da Cunha M (2001) Impact of cephalopods in the food chain and their interaction with the environment and fisheries: an overview. Fish Res 52: $5-10$

Raclot T, Groscolas R, Cherel Y (1998) Fatty acid evidence for the importance of myctophid fishes in the diet of king penguins, Aptenodytes patagonicus. Mar Biol 132: 523-533

Reinhardt SB, Van Vleet ES (1986) Lipid composition of twenty-two species of Antarctic midwater zooplankton and fish. Mar Biol 91:149-159

Rodhouse PG, White MG (1995) Cephalopods occupy the ecological niche of epipelagic fish in the Antarctic Polar Frontal Zone. Biol Bull 189:77-80

Rodhouse PG, White MG, Jones MRR (1992) Trophic relations of the cephalopod Martialia hyadesi (Teuthoidea: Omma- 
strephidae) at the Antarctic Polar Front, Scotia Sea. Mar Biol 114:415-421

Rodhouse P, Olsson O, Anker-Nilssen P, Murray A (1998) Cephalopod predation by the king penguin Aptenodytes patagonicus from South Georgia. Mar Ecol Prog Ser 168: 13-19

Saito H, Murata M (1996) The high content of monoene fatty acids in the lipids of some midwater fishes: family Myctophidae. Lipids 31:757-763

Saito H, Murata M (1998) Origin of the monoene fats in the lipid of midwater fishes: relationship between the lipids of myctophids and those of their prey. Mar Ecol Prog Ser 168: 21-33

Sargent JR (1976) The structure, metabolism and function of lipids in marine organisms. In: Malins DC, Sargent JR

Editorial responsibility: Otto Kinne (Editor), Oldendorf/Luhe, Germany (eds) Biochemical and biophysical perspectives in marine biology, Vol 3. Academic Press, London, p 149-212

Semmens JM (1998) An examination of the role of the digestive gland of two loliginid squids, with respect to lipid: storage or excretion? Proc R Soc Lond Ser B 265: 1685-1690

Smale MJ, Watson G, Hecht T (1995) Otolith atlas of Southern African marine fishes. JLB Smith Institute of Ichthyology, Grahamstown

Smith MM, Heemstra PC (1986) Smith's sea fishes. Southern Book Publishers, Johannesburg

Williams R, McEldowney A (1990) A guide to the fish otoliths from waters off the Australian Antarctic Territory, Heard and Macquarie Islands. Australian National Antarctic Research Expeditions, Hobart, ANARE Research Notes 75

Submitted: August 12, 2002; Accepted: March 4, 2003 Proofs received from author(s): June 24, 2003 